\title{
RITUXIMAB DOES NOT ADVERSELY AFFECT THE STEM CELL MOBILIZATION AND ENGRAFTMENT AFTER HIGH-DOSE THERAPY AND AUTOLOGOUS TRANSPLANTATION IN PATIENTS WITH DIFFUSE LARGE B-CELL LYMPHOMA IN FIRST COMPLETE OR PARTIAL REMISSION
}

\author{
Tomas Papajik ${ }^{\mathrm{a}}$, Zuzana Pikalova ${ }^{\mathrm{a}}$, Ludek Raida ${ }^{\mathrm{a}}$, Ivana Skoumalovaa, Jana Vondrakovaa, \\ Edgar Faber ${ }^{a}$, Vit Prochazka ${ }^{a}$, Zuzana Kubova ${ }^{a}$, Ladislava Kucerova ${ }^{b}$, Tomas Pavlikc, \\ Ladislav Dusek ${ }^{c}$, Karel Indrak ${ }^{\mathrm{a}}$
}

a Department of Hemato-oncology, Palacky University, Olomouc,

${ }^{b}$ Department of Pathology, Palacky University, Olomouc,

c Institute of Biostatistics and Analyses, Masaryk University, Brno, Czech Republic

Received: February 10, 2009; Accepted: September 3, 2009

Key words: Diffuse large B-cell lymphoma/Rituximab/Stem cell transplantation

Aims and Methods: The goal was to investigate the effect of prior combined rituximab (R) and intensive chemotherapy on peripheral blood stem cell mobilization and their engraftment after stem cell transplantation (ASCT) in 69 patients with poor-risk, diffuse large B-cell lymphoma (DLBCL).

Results: A statistically comparable median number of CD34+ stem cells was collected in both groups (13.80x $10^{6} /$ $\mathrm{kg}$ in the non-R group and $7.81 \times 10^{6} / \mathrm{kg}$ in the R group; $\mathrm{p}=0.110$ ). A trend toward greater number of CFU-GM was found in the non- $\mathrm{R}$ group $\left(98.1 \times 10^{4} / \mathrm{kg}\right)$ compared to the $\mathrm{R}$ group $\left(76.6 \times 10^{4} / \mathrm{kg} ; \mathrm{p}=0.068\right)$. The non $\mathrm{R}$ patients had a much higher median number of BFU-E $\left(90.9 \times 10^{4} / \mathrm{kg}\right)$ than the R patients $\left(31.3 \times 10^{4} / \mathrm{kg} ; \mathrm{p}=0.001\right)$.

Conclusions: Hematopoietic engraftment was rapid for both groups and no different between them. The 3-year event-free survival was $90.4 \%$ in the R group and $67.2 \%$ in the non-R group $(\mathrm{p}=0.04)$, but there was no significant difference in the 3 -year overall survival $(94,7 \%$ vs $83,5 \%$; $=0.179)$.

\section{INTRODUCTION}

The addition of rituximab (humanized chimeric antiCD20 monoclonal antibody, R) to chemotherapy (CT) leads to higher response rates and improved survival for patients with diffuse large B-cell lymphoma (DLBCL) ${ }^{1,2}$. It has also been reported that $\mathrm{R}$ is effective in removing circulating $\mathrm{B}$ cells from peripheral blood and this might be a useful in vivo purging agent before stem cell harvesting $^{3}$. Several studies have indicated that the combination of $\mathrm{R}$ with chemotherapy does not compromise the mobilization and engraftment of autologous peripheral blood stem cells (PBSC) in lymphoma patients and some have also pointed to improved patient survival ${ }^{4-6}$. However, the overall feasibility and effectiveness of adding $\mathrm{R}$ to intensified first-line CT followed by autologous stem-cell transplantation (ASCT) in poor-risk patients remains to be established ${ }^{7}$. In this retrospective study, the effect of prior combined $\mathrm{R}$ and $\mathrm{CT}$ administration on peripheral blood stem cell mobilization and post-transplant engraftment was analyzed and compared with the results of patients previously treated without $\mathrm{R}$.

\section{PATIENTS AND METHODS}

\section{Patient population}

From May 1999 to August 2007, sixty-nine ASCTs for DLBCL were performed in poor-risk patients younger than 65 years who had achieved complete remission $(\mathrm{CR})$ or partial remission (PR) after induction CT $(\mathrm{n}=31)$ or $\mathrm{R}$ with CT $(\mathrm{n}=38)$. Poor risk was defined as International Prognostic Index (IPI) 3-5 or age-adjusted IPI (aaIPI) 2-3 (for patients younger than 60 years), IPI 1-2 or aaIPI 1 with one or more additional adverse prognostic parameters (bulky disease more than $10 \mathrm{~cm}$ in largest diameter, beta-2-microglobulin more than $3.0 \mathrm{mg} / 1$, bcl-2 protein expression in immunohistochemical staining), and failure to achieve CR irrespective of the patient's initial IPI/aaIPI. Three patients were primarily treated with 6 courses of the ProMACE-CytaBOM regimen, and 3 patients with 6 courses of the PACEBO regimen. All other patients received intensive sequential CT consisting of 3 courses of PACEBO, 1 course of IVAM (with ifosfamide $1500 \mathrm{mg}$ / $\mathrm{m}^{2}$ and methotrexate $3 \mathrm{~g} / \mathrm{m}^{2}$ ), and 1 course of HAM (cytosine arabinoside $2 \mathrm{~g} / \mathrm{m}^{2}$ twice daily on days 1 to 2 , mitoxantrone $10 \mathrm{mg} / \mathrm{m}^{2}$ on days 2 to 3 ). $\mathrm{R} 375 \mathrm{mg} / \mathrm{m}^{2}$ was administered on day 1 of the CT regimens in 38 (55\%) patients. The treatment protocols were reviewed and approved by our institutional review board, the Independent Ethics Committee of the University Hospital Olomouc, and written informed consent was obtained from all patients in accordance with the Declaration of Helsinki.

\section{Mobilization and harvesting of CD34+ cells}

PBSC were mobilized after CE (cyclophosphamide $4 \mathrm{~g} / \mathrm{m}^{2}$ on day 1 , etoposide $200 \mathrm{mg} / \mathrm{m}^{2}$ on days 1 to 3 ) in 6 cases or after HAM in 60 cases followed by $5 \mu \mathrm{g} / \mathrm{kg}$ 
Table 1. Results of peripheral blood stem cells collection.

\begin{tabular}{|l|c|c|c|}
\hline Variable & $\begin{array}{c}\text { Chemotherapy } \\
(\mathrm{n}=31)\end{array}$ & $\begin{array}{c}\text { R-chemotherapy } \\
(\mathrm{n}=38)\end{array}$ & p-value \\
\hline $\begin{array}{l}\text { Median number of mononuclear cells } \\
\left(\mathrm{x} 10^{8} / \mathrm{kg}\right)\end{array}$ & 3.77 & 5.24 & 0.800 \\
\hline $\begin{array}{l}\text { Median number of CD34+ cells }\left(\mathrm{x} 10^{6} /\right. \\
\mathrm{kg})\end{array}$ & 13.80 & 7.81 & 0.110 \\
\hline $\begin{array}{l}\text { Number of patients with } \\
\geq 5.0 \mathrm{x} 10^{6} \mathrm{CD} 34+\text { cells/kg }\end{array}$ & $26(84 \%)$ & $35(92 \%)$ & 0.480 \\
\hline Median number of CFU-GM $\left(\mathrm{x} 10^{4} / \mathrm{kg}\right)$ & 98.1 & 76.6 & 0.068 \\
\hline $\begin{array}{l}\text { Median number of BFU-E } \\
\left(\mathrm{x} 10^{4} / \mathrm{kg}\right)\end{array}$ & 90.9 & 31.3 & 0.001 \\
\hline
\end{tabular}

body weight of filgrastim from day 8 . The PBSC were collected by leukapheresis (COBE Spectra cell separator, Lakewood, CO, USA) with a targeted minimum cell count $>2 \times 10^{6} / \mathrm{kg}$ body weight of CD $34+$ cells and then cryopreserved without purging or CD34+ selection. The BEAM conditioning regimen (BCNU $300 \mathrm{mg} / \mathrm{m}^{2}$, etoposide $800 \mathrm{mg} / \mathrm{m}^{2}$, cytosine arabinoside $1600 \mathrm{mg} / \mathrm{m}^{2}$, and melphalan $140 \mathrm{mg} / \mathrm{m}^{2}$ ) was given to all 69 patients. The cryopreserved cells were reinfused on day 0 .

\section{Analysis of harvested stem cells}

The sample of leukapheresis product $(50 \mu 1)$ was stained with phycoerythrin-conjugated $(5 \mu \mathrm{l})$ anti-CD34 (Clone 581, Immunotech, Marseille, France). Cells were subsequently lysed for 15 minutes, centrifuged, washed twice, and resuspended in PBS and analyzed with the FACSCalibur flow cytometer (BectonDickinson, San Jose, CA, USA). All samples were gated on a leukocyte window and 60,000 events were collected in this region. A double-layer methylcellulose progenitor cell assay system with GM-CSF and EPO was used to quantify granulocyte-macrophage colony-forming units (CFU-GM) and burst-forming units-erythroid (BFU-E), as previously described $^{8-10}$. MNCs were plated at 20.000 cells per $35-\mathrm{mm}$ culture dish $(1 \mathrm{ml})$. Cultures were incubated at $37{ }^{\circ} \mathrm{C}$ for 14 days in a $100 \%$ humidified incubator with $5 \% \mathrm{CO}_{2}$ and $10 \% \mathrm{O}_{2}$ in air. Day-14 GM-CFC-derived colonies were defined as any colony containing more than 40 translucent cells; day-14 BFU-E-derived colonies were defined as any colony. CFU-GM and BFU-E were counted using an inverted microscope.

\section{Engraftment kinetics, response and statistical methods}

Neutrophil recovery was defined as the first of 3 consecutive days with a neutrophil count greater than $0.5 \times 10^{9} / 1$; platelet recovery was defined as the first of 3 consecutive days with an unsupported platelet count greater than $20 \times 10^{9} / 1$. The times to recover $1.0 \times 10^{9} / 1$ granulocytes, $50 \times 10^{9} / 1$ and $100 \times 10^{9} / 1$ platelets after ASCT were also recorded. The numbers of granulocytes and platelets and $\mathrm{Hb}$ values were analyzed on day +100 after ASCT. Response to therapy was assessed using the International Working Group criteria published in
$1999^{10}$. Survival curves were constructed based on the Kaplan-Meier methodology. The statistical analyses were performed using Statistica for Windows 7.1 (StatSoft Inc., 2005) and SPSS 12.0.1 (SPSS Inc., 2003).

\section{RESULTS}

Patient prognostic characteristics and response to induction chemotherapy were well-balanced between the CT and R-CT groups. Statistically comparable cumulative numbers of mononuclear cells (MNCs) were collected in both groups, with medians of $3.77 \times 10^{8} \mathrm{MNCs} / \mathrm{kg}$ (range, 1.52 to $11.81 \times 10^{8} / \mathrm{kg}$ ) in the non-R group, and $5.24 \times 10^{8}$ $\mathrm{MNCs} / \mathrm{kg}$ (range, 2.17 to $17.89 \times 10^{8} / \mathrm{kg}$ ), in the $\mathrm{R}$ group $(\mathrm{p}=0.800)$. The same was true for CD34+ stem cells $13.80 \times 10^{6} \mathrm{CD} 34+$ cells $/ \mathrm{kg}$ (range, 2.76 to $39.50 \times 10^{6} / \mathrm{kg}$ ) were collected in the non-R group and $7.81 \times 10^{6} \mathrm{CD} 34+$ cells $/ \mathrm{kg}$ (range, 3.15 to $37.30 \times 10^{6} / \mathrm{kg}$ ) in the $\mathrm{R}$ group $(p=0.110)$. There was no significant difference in the numbers of those with more than $5.0 \times 10^{6} / \mathrm{kg}$ CD34+ cells $/ \mathrm{kg}$ between non-R patients ( $84 \%$ ) and $\mathrm{R}$ patients ( $92 \% ; p=0.480)$. A trend toward a greater number of CFU-GM was observed in the non-R group (median, $98.1 \times 10^{4} / \mathrm{kg}$; range, $\left.24.2-269.1 \times 10^{4} / \mathrm{kg}\right)$ in comparison with the R-group (median, $76.6 \times 10^{4} / \mathrm{kg}$; range 11.5 - 216.9x10 $/ \mathrm{kg})(\mathrm{p}=0.068)$. A statistically significant difference between the non- $R$ and $R$ groups was found in the number of BFU-E. The non-R patients had a much higher median number of BFU-E $\left(90.9 \times 10^{4} / \mathrm{kg}\right.$; range, 8.8 - $\left.337.0 \times 10^{4} / \mathrm{kg}\right)$ than the $\mathrm{R}$ patients $\left(31.3 \times 10^{4} / \mathrm{kg}\right.$; range, $\left.1.4-191.0 \times 10^{4} / \mathrm{kg}\right)(\mathrm{p}=0.001)$ (Table 1). Hematopoietic engraftment was rapid, with median neutrophil recovery of 11 days in both groups $(p=0.420)$ and median platelet recovery of 10 days in the non- $R$ and $R$ groups $(p=0.530)$. The times to recover $1.0 \times 10^{9} / 1$ granulocytes, $50 \times 10^{9} / 1$ and $100 \times 10^{9} / 1$ platelets after transplantation were nearly similar in the two groups and were statistically non-significant as well as the numbers of granulocytes and platelets and hemoglobin values on day +100 after ASCT. No differences in toxicity or serious complications in the non- $R$ and R groups after ASCT were found. No toxic or transplant-related death was reported. The median follow-up 
was 59.9 and 29.2 months for the non-R and $\mathrm{R}$ groups, respectively. The number of relapses was higher in the non-R patients $(9 / 31 ; 29 \%)$ compared with the $\mathrm{R}$ patients $(2 / 38 ; 5 \%)(p=0.009)$. The administration of $\mathrm{R}$ was associated with lower number of deaths due to lymphoma progression ( $3 \%$ vs. $19 \%, p=0.04$ ). The probability of 3-year event-free survival (EFS) was $77.2 \%$ (95\% CI, 66 to 89 $\%)$ in all 69 patients. The 3-year EFS was significantly higher in the R group (90.4\%) than in the non-R group $(67.2 \%)(p=0.04)$ (Fig. 1a). The probability of 3-year overall survival (OS) was $88.4 \%$ (95\% CI, 80 to $97 \%$ ) but no significant difference between the R (94.7\%) and non-R groups ( $83.5 \%$ ) was noted ( $\mathrm{p}=0.179$ ) (Fig. 1b). No patient developed a second malignancy or myelodysplastic syndrome to the date of analysis.

\section{DISCUSSION}

$\mathrm{R}$ combined with $\mathrm{CT}$ is a safe and effective first-line treatment for patients with CD20+ DLBCL. Previous studies have reported improved remission and survival rates in low-risk young patients and patients older than 60 years $^{1,2}$. Little data are available regarding the effective- ness and safety of $\mathrm{R}$ administered in combination with intensified CT eventually followed by PBSC mobilization, harvesting and ASCT after myeloablative $\mathrm{CT}^{4,7,12,13}$. This study represents a retrospective analysis of patients with poor-risk DLBCL treated with myeloablative CT with ASCT in first CR or PR in our center. The aim was to investigate whether repeated use of $\mathrm{R}$ with $\mathrm{CT}$ prePBSC mobilization results in impaired stem cells yield, prolonged engraftment, increased complications or worse survival of these patients.

The results show that prior R-CT had no significant effects on mobilization of MNCs or CD34+ cells. R-CT even resulted in slightly higher but non-significant optimal mobilization rate $\left(\geq 5.0 \times 10^{6} / \mathrm{kg} \mathrm{CD} 34+\right.$ cells $/ \mathrm{kg}$ in $92 \%$ vs. $84 \%$ of patients). These findings are consistent with earlier studies which indicate that $\mathrm{R}$ has no negative affects on PBSC mobilization kinetics ${ }^{6,14,15}$. In this study, the in vitro growth of harvested progenitor cells was investigated and the median number of CFU-GM was shown to be higher in patients previously treated only with CT $\left(98.1 \times 10^{4} / \mathrm{kg}\right)$ in comparison with those treated and mobilized after R-CT $\left(76.6 \times 10^{4} / \mathrm{kg}\right)$, although the statistical significance was only borderline $(p=0.068)$. Significant difference between the two groups was found for BFU-E
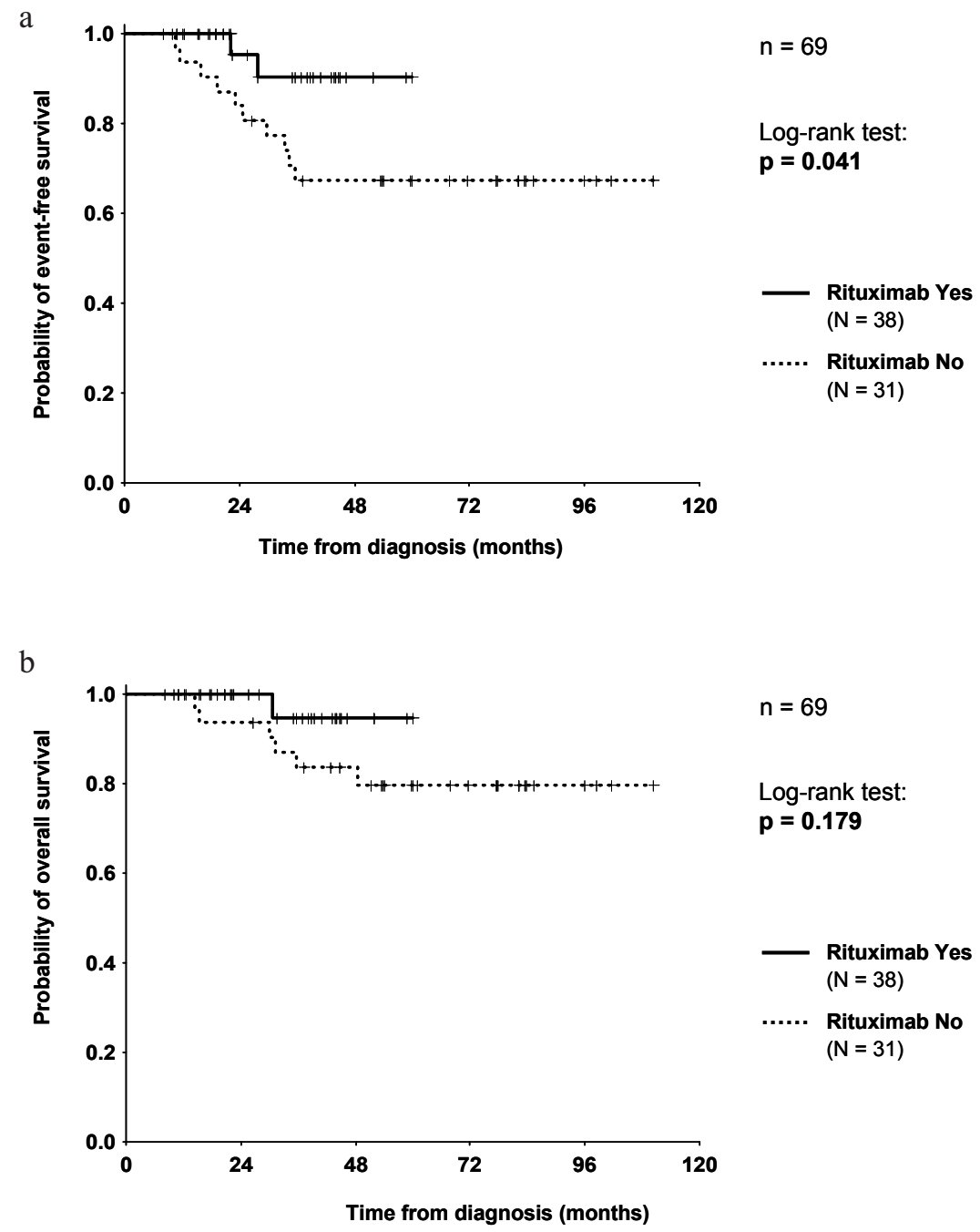

Fig. 1. EFS (a) and OS (b) for DLBCL patients initially treated with rituximab plus chemotherapy or with chemotherapy alone. 
progenitor cells. The non-R patients had a BFU-E median number of $90.9 \times 10^{4} / \mathrm{kg}$ whereas the R-CT patients had the BFU-E median of $31.3 \times 10^{4} / \mathrm{kg}(\mathrm{p}=0.001)$. The etiology and importance of this phenomenon is unclear. Activation of the complement and some inflammatory cytokines (i.e. tumor necrosis factor-alpha) by rituximab may lead to non-specific bystander lysis or inhibition of some stem cells compartments ${ }^{16,17}$. On the other hand, a majority of studies confirm that only CD34+ cell subsets are significantly associated with short-term and long-term hematopoietic reconstitution ${ }^{18}$. Our data support previous publications reporting that R-CT has no impact on the engraftment and function of PBSC after ASCT and that this approach may improve survival of DLBCL patients ${ }^{14,15,19}$. In this study, the times to recover granulocytes and platelets after transplantation were similar in the non-R and $\mathrm{R}$ groups as well as the numbers of granulocytes and platelets and hemoglobin values on day +100 after transplantation. Also, no difference was found in toxicity and serious complications after ASCT, no toxic or transplant-related death, second malignancy or myelodysplastic syndrome were reported. Although the follow-up was significantly different in the non- $\mathrm{R}$ and $\mathrm{R}$ groups, the number of relapses and deaths due to lymphoma progression was significantly higher in the non-R patients. The 3-year EFS was significantly higher in the R group (90.4\%) than in the non-R group $(67.2 \%)(p=0.04)$, but the OS mainly due to lower number of patients and salvage therapy with rituximab or allogeneic transplantation in relapsed non- $R$ patients was not different. The conclusion is that $\mathrm{R}$ with intensive CT has no negative affect on the mobilization and engraftment of PBSC and reduces relapse rate in poor-risk DLBCL patients.

\section{ACKNOWLEDGEMENT}

Supported by VZ MSM 6198959205 and 619895922 grants.

\section{REFERENCES}

1. Feugier P, Van Hoof A, Sebban C, Solal-Celigny P, Bouabdallah $\mathrm{R}$, Fermé C, et al. Long-term results of the R-CHOP study in the treatment of elderly patients with diffuse large B-cell lymphoma: a study by the Groupe d'Etude des Lymphomes de l'Adulte. J Clin Oncol. 2005; 23: 4117-26.

2. Pfreundschuh M, Trümper L, Osterborg A, Pettengell R, Trneny $\mathrm{M}$, Imrie K, et al. CHOP-like chemotherapy plus rituximab versus CHOP-like chemotherapy alone in young patients with goodprognosis diffuse large-B-cell lymphoma: a randomised controlled trial by the MabThera International Trial (MInT) Group. Lancet Oncol. 2006; 7: 379-91.

3. Belhadj K, Delfau-Larue MH, Elgnaoui T, Beaujean F, Beaumont JL, Pautas C, et al. Efficiency of in vivo purging with rituximab prior autologous peripheral blood progenitor cell transplantation in B-cell non-Hodgkin's lymphoma. A single institution study. Ann Oncol. 2004; 15: 504-10.

4. Vitolo U, Cabras MG, Rossi G, Anna Marina Liberati AM, Chiappellaet A, et al. Rituximab as Adjuvant to Dose-Dense and High Dose Chemotherapy (HDC) with Autologous Stem Cell Transplantation (ASCT) as First Line Treatment in Stage III-IV
Diffuse Large B-Cell Lymphoma (DLBCL) at Poor Prognosis: Final Analysis of Phase II GIMURELL Trial. Blood 2006; 108: 329a.

5. Hoerr AL, Gao F, Hidalgo J, Tiwari D, Blum KA, Mathews V, et al. Effects of pretransplantation treatment with rituximab on outcomes of autologous stem-cell transplantation for non-Hodgkin's lymphoma. J Clin Oncol. 2004; 22: 4561-6.

6. Kamezaki K, Kikushige Y, Numata A, Miyamoto T, Takase K, Henzan H, et al. Rituximab does not compromise the mobilization and engraftment of autologous peripheral blood stem cells in diffuse-large B-cell lymphoma. Bone Marrow Transplant. 2007; 39: 523-7.

7. Milpied N, Lamy T, Casassus P, Deconninck E, Gressin R, Le Maignan C, et al. Front-line high-dose chemotherapy (HDT) combined with rituximab for adults with aggressive large B cell lymphoma (DLBCL). A pilot study by the GOELAMS. J Clin Oncol. 2004; 22 (Suppl.): 6662.

8. Bradley TR, Hodgson GS, Rosendaal M. The effect of oxygen tension on haemopoietic and fibroblast cell proliferation in vitro. $\mathrm{J}$ Cell Physiol. 1978; 94: 517-22.

9. Nemunaitis J, Singer JW, Buckner CD, Hill R, Storb R, Thomas $\mathrm{ED}$, et al. Use of recombinant human granulocyte-macrophage colony stimulating factor in autologous bone marrow transplantation. Blood 1988; 72: 834-6.

10. Edvardsson L, Dykes J, Olsson ML, Olofsson T. Clonogenicity, gene expression and phenotype during neutrophil versus erythroid differentiation of cytokine-stimulated CD34+ human marrow cells in vitro. Br J Haematol. 2004; 127: 451-463.

11. Cheson BD, Horning SJ, Coiffier B, Gascoyne RD, Specht L, Horning SJ, et al. Report of an international workshop to standardize response criteria for non-Hodgkin's lymphomas. J Clin Oncol. 1999; 17: 1244-53.

12. Tarella C, Zanni M, Di Nicola M, Patti C, Calvi R, Pescarollo A, et al. Prolonged survival in poor-risk diffuse large B-cell lymphoma following front-line treatment with rituximab-supplemented, earlyintensified chemotherapy with multiple autologous hematopoietic stem cell support: a multicenter study by GITIL (Gruppo Italiano Terapie Innovative nei Linfomi). Leukemia 2007; 21:1802-1811.

13. Chiappella A, Rossi G, Cabras MG, Liberati AM, Ciccone G, Salvi F, et al. Rituximab (R) in Addition to Dose-Dense Chemotherapy MegaCEOP and Intensification with R-MAD Followed by High Dose Chemotherapy BEAM with Autologous Stem Cell Transplantation (ASCT) Is Safe and Effective in Untreated High Risk Diffuse Large B-Cell Lymphoma (DLBCL). Blood 2007; 110: 1899a.

14. Botto B, Vitolo U, Cortelazzo S, Chiappella A, Allione B, Angelucci E, et al. Pre-Autologous Stem Cell Transplantation (ASCT) Treatment with Rituximab Does Not Impair Stem Cell Harvest and Engraftment in Untreated Patients with Diffuse Large B-Cell Lymphoma (B-DLCL) at Poor Prognosis. Blood 2005; 106: 2738a.

15. Hosing C, Saliba RM, Körbling M, Acholonu S, McMannis J, Anderlini $\mathrm{P}$, et al. High-dose rituximab does not negatively affect peripheral blood stem cell mobilization kinetics in patients with intermediate-grade non-Hodgkin's lymphoma. Leuk Lymphoma 2006; 47: 1290-4.

16. Bienvenu J, Chvetzoff R, Salles G, Balter C, Tilly H, Herbrecht R, et al. Tumor necrosis factor alpha release is a major biological event associated with rituximab treatment. Hematol J. 2001; 2: 378-84.

17. van der Kolk LE, Grillo-López AJ, Baars JW, Hack CE, van Oers MH. Complement activation plays a key role in the side-effects of rituximab treatment. Br J Haematol. 2001; 115: 807-11.

18. Jansen EM, Hanks SG, Terry C, Akard LP, Thompson JM, Dugan MJ, et al. Prediction of engraftment after autologous peripheral blood progenitor cell transplantation: CD34, colony-forming unitgranulocyte-macrophage, or both? Transfusion. 2007; 47: 817-823.

19. Fenske TS, Hari P, Carreras J, Zhang MJ, Kamble R, Rizzo JD, et al. Pre-Transplant Rituximab Therapy Is Associated with Improved Progression-Free and Overall Survival in Patients Undergoing Autologous Hematopoietic Stem Cell Transplantation for Diffuse Large B-Cell Lymphoma (DLBCL). Blood 2007; 110: 19a. 